\title{
Executive Compensation and Competition in the Banking
} and Financial Sectors

By

Vicente Cuñat

Maria Guadalupe

DISCUSSION PAPER NO 598

\author{
DISCUSSION PAPER SERIES
}

October 2007

Vicente Cuñat is a Lecturer in the Department of Finance of the London School of Economics and Political Science (LSE). He received his $\mathrm{PhD}$ in Economics from the LSE. His areas of expertise are related to Corporate Finance and Industrial Organization. In particular to what is the optimal financial structure of firms; how do suppliers and buyers interact commercially and financially; what are the effects of financing constraints on firm decisions; and how do firms change the incentive packages that they provide to their workers when their competitive environment changes. Professor Guadalupe received her PhD in Economics from the LSE in 2003, spent a year as visiting scholar at MIT and joined Columbia Business School as an Assistant Professor in July 2004. Her research interests are in the area of Labor Economics and the Economics of Personnel and Organizations. In her work, she has studied the effect of changes in the degree of competition in the product market that firms face on their internal behaviour. In particular she has shown how increased product market competition leads to higher returns to skill and therefore increased wage inequality. Guadalupe has also studied the effect of the competitive environment on the compensation packages that firms offer to their executives and the degree to which they use performance related pay. Any opinions expressed here are those of the authors and not necessarily those of the FMG. The research findings reported in this paper are the result of the independent research of the authors and do not necessarily reflect the views of the LSE. 


\title{
Executive Compensation and Competition in the Banking and Financial Sectors.
}

\author{
Vicente Cuñat \\ The London School of Economics
}

\author{
Maria Guadalupe* \\ Columbia University \\ CEPR
}

\begin{abstract}
This paper studies the effect of deregulation and increased product market competition on the compensation packages that firms offer to their executives. We use a panel of US executives in the nineties and exploit the deregulation episodes in the banking and financial sectors as quasi-natural experiments. We provide difference-in-differences estimates of their effect on (1) total pay, (2) estimated fixed pay and performance-pay sensitivities and (3) on the sensitivity of stock option grants. Our results indicate that the deregulations substantially changed the level and structure of compensation: the variable components of pay increased, performance-pay sensitivities grew and, at the same time, the fixed component of pay fell. The overall effect on total pay was small.
\end{abstract}

JEL codes: M52, L1, J31

Keywords: Executive compensation; performance related pay; incentives; product market competition; deregulation.

\footnotetext{
${ }^{*}$ We would like to thank Heski Bar-Isaak, Ken Troske, Mariassunta Gianetti, Maia Güell, Marco Manacorda, Sendhil Mullainathan, Steve Nickell, Mitchell Petersen, Steve Pischke, Masako Ueda, John Van Reenen and participants at seminars in LSE, MIT, UPF, CEMFI, IZA, Gerzensee and ASSA meetings for helpful comments. Any remaining errors are our sole responsibility. We would like to thank the financial support from Fundación Ramón Areces, Spanish Ministry of Education and Science (grant SEJ200503924/ECON) and from the Centre de Referència en Economia Analítica (CREA-Barcelona Economics). Corresponding author: Maria Guadalupe, a: Columbia Business School, 3022 Broadway, Uris Hall 624, New York NY 10027 e: mg2341@columbia.edu p: (+1) 2128546176 f: (+1) 2123169219
} 


\section{Introduction}

The level and structure of executive compensation changed considerably over the $80 \mathrm{~s}$ and 90s. There was a sharp increase in the level of CEO and executive pay, and in the sensitivity of pay to performance in executive contracts. Furthermore, the use of stock options grew substantially and now tends to dominate compensation packages for top executives (Hall and Liebman, 1998; Murphy, 1999). Murphy and Zábojník (2004a; 2004b) provide an explanation for the increase in CEO pay and the increase in hiring of external CEOs based on an increase in the demand for managerial ability that is transferable across firms relative to firm specific human capital. However, little is known on the economic forces that lead firms to alter the compensation packages they offer to their executives and the incentives they provide.

A potentially large contributor to changes in contracts, that has substantial theoretical support, are changes in the configuration of the product market. This theoretical literature shows how, in a principal agent framework, firms may alter the structure of the incentive contracts they offer to their executives, as a response to changing product market competition (Schmidt, 1997; Raith, 2003; Hart, 1983; Scharfstein, 1988; and Hermalin, 1992). However, these papers do not provide unambiguous predictions on the effect of competition on the sensitivity of pay to performance. Therefore testing what are the relevant effects that dominate empirically is an important exercise. ${ }^{1}$

In this paper we study to what extent changes in executive pay are driven by changes in the structure of the product market and, more generally, in competition. To assess the effect of changes in product market structure on executive pay, we focus on an industry, the financial sector, that went through sizeable changes during the $90 \mathrm{~s}^{2}{ }^{2}$ This has the advantage that, to the extent that these changes are exogenous to executive wage setting, we are able to provide a causal estimate of the effect of competition on the structure of pay. We study

\footnotetext{
${ }^{1}$ The theoretical papers that analyze the expected effects of changes in product market competition on incentives and contracts within the principal agent paradigm, have identified the following channels. First, competition changes the elasticity of profits to increases in productivity and therefore also the returns to managerial effort (Schmidt, 1997; Raith, 2003). Following a change in the competitive environment, firms may decide to re-optimize their compensation package. Second, competition changes the risk and implicit incentives that the economic environment provides to managers (Schmidt, 1997) as well as the amount of information available to principals (Hart, 1983; Scharfstein, 1988; and Hermalin, 1992). This alters the effort exerted by executives and may change the optimal incentive package offered by firms. Finally, and possibly departing from the standard principal-agent approach, changes in competition may alter firm profits, relative bargaining power and the incentives for managers to extract rents (Bebchuk, Fried and Walker, 2002; Bertrand and Mullainathan, 2001).

${ }^{2}$ Murphy (1999) reports that the sensitivity of pay to performance in the financial sector went from $\$ 3.54$ in 1992 to $\$ 5.34$ in 1996 per thousand dollars of shareholder wealth, half of which is given by stock options.
} 
how both the overall level of pay and its composition changed over that period.

The financial sector underwent two substantial deregulations in the 90s that considerably altered the nature and intensity of product market competition by lowering entry barriers. The first was the 1994 Riegle-Neal Interstate Banking and Branching Efficiency Act, that eliminated all restrictions to interstate banking and implied that all commercial banks were allowed to own and operate branches in different states. The second was the 1999 Gramm-Leach-Bliley Act, also known as the financial services modernization act. This repealed previous legislation that imposed barriers separating traditional banking, insurance and securities underwriting into three distinct industries, which in practice meant that commercial banks, insurance companies and investment firms were not competing with each other.

These deregulation episodes, lowered barriers to entry and actually implied an increase in product market competition in the deregulated sectors. We provide a discussion of the evidence on changes to these industries following the deregulations that suggests a substantial impact on the intensity of competition. We therefore exploit these two large deregulations to assess the effect of product market changes on total pay as well as its differential effect on fixed and performance-related pay.

An interesting feature of these deregulations, to the extent that they are exogenous, is that they can be thought of as a quasi-natural experiment, and therefore allow us to obtain an arguably causal effect of competition on the structure of pay. We use the deregulations to provide difference-in-differences estimates of their effect on compensation contracts. Difference-in-differences estimates compare the change in contracts between the deregulated industries and a control group before and after the deregulation, such that they are net of pre-existing differences in contracts or general time changes in performance-related pay.

We use a panel of firms that report detailed compensation information on at least their five most highly paid executives (the S\&P Execucomp dataset) to measure the effect of the deregulations on the structure of compensation net of other aggregate changes. Estimating individual compensation equations that account for firm and individual characteristic we obtain a difference-in-differences estimate of (1) the change in total pay and (2) the level of fixed pay and the slope of performance-pay contracts, following the deregulations. In addition to this, (3) we estimate the impact of the deregulation on the sensitivity of stock options granted to firm performance.

Our results show that total executive pay marginally increases in deregulated sectors relative to the control group, following both deregulations. However, this masks a differential effect on the various components of pay. While fixed pay falls, performance related pay rises and represents a larger fraction of total pay. In addition to this, we show that not only does 
the total amount of variable pay increase, but the sensitivity of pay to performance also increases. Firms provide more high powered incentives following the deregulation in the deregulated industries. This is true for different measures of sensitivity, and for alternative specifications of both deregulations.

We also perform a number of robustness checks. In particular, we allow for the existence of Relative Performance Evaluation (RPE) in compensation contracts following Aggarwal and Samwick (1999), Joh (1999) and Kedia (2006). These papers introduce explicitly strategic considerations and the structure of the product market in managerial compensation to address the relative performance evaluation puzzle. ${ }^{3}$ Our approach is distinct in the sense that using exogenous shocks to the competitive environment in which firms operate means we identify a causal effect from product market competition (the deregulations) to executive compensation, and not the reverse.

The added value of our work is therefore to clarify the effect of changes in the competitive environment following these deregulations on various aspects of the compensation packages offered to executives. We show that the increase in pay sensitivities and the substitution of fixed for variable pay are results of increasing competition. We also complement and extend the results in Hubbard and Palia (1995) and Crawford et al. (1995) that analyze the effect of State banking deregulations in the 80s on CEO compensation. These papers show a positive effect of State deregulations on total pay, and the fixed component of compensation (in a difference-in-differences setting); and even though they present suggestive evidence of an increase in performance-pay sensitivities, they do not provide difference-in-difference estimates of these. ${ }^{4}$ We provide full difference-in-differences estimates on the effect of the 90s deregulations on the structure of compensation, on performance-pay sensitivities and on the sensitivity of stock options, and document the substitution away from fixed pay to variable pay. We thus can argue that we find a causal effect of the deregulations on these magnitudes.

The effect of deregulations, and the implied increase in product market competition, on the composition of pay is a relatively unexplored question at an empirical level. This is so, even though a number of theoretical papers have implications regarding this interaction. Joskow et al. (1993) and (1996) show that regulated utilities pay lower wages than the unregulated sectors, and also indicate that they provide less sensitive compensation pack-

\footnotetext{
${ }^{3}$ The 'puzzle' refers to the fact that empirical studies seem not to find any role for relative performance evaluation in incentive contracts.

In particular, these papers argue that principals commit to particular compensation structures to soften or increase the aggressiveness of their managers in the output market. In their setting competition is endogenous to the compensation structure.

${ }^{4}$ Black and Strahan (2001) using the same deregulations find that overall wages fell for workers.
} 
ages. Their evidence, however, relies mainly on cross sectional differences between sectors. Cuñat and Guadalupe (2005), move away from deregulations and use a source of variation in competition based on an exchange rate shock to show that higher levels of competition increased the sensitivity of performance related pay schemes in the UK. ${ }^{5}$ A significant contribution of this paper is to show that increased competition and deregulations have important consequences in terms of explaining recent trends in executive compensation, such as the increased reliance on stock options and the higher performance-pay sensitivities, and to do so with an econometric specification that allows us to claim the estimates we find are plausibly causal.

The structure of the rest of the paper is as follows: section 2 discusses the theoretical background of our analysis; section 3 shows the identification strategy and explains the two deregulation episodes; section 4 presents the specifications and results, and section 5 concludes.

\section{Theoretical Background}

To the extent that the deregulations imply a fall in entry barriers, one can assimilate them to higher competitive pressure in the product market (we address the evidence on this in the next section). In what follows we discuss the theoretical literature on the relationship between competition and compensation.

Schmidt (1997) and Raith (2003) take as a starting point the effect of competition on the distribution of profits across firms in the product market, and study the implied impact on executive compensation in a principal agent setting. In Schmidt (1997) the explicit contract signed by a risk neutral principal (shareholders) and a risk averse agent that can exert effort in cost-cutting activities (CEO, executive) is influenced by the implicit incentives given by the competitive environment of the firm. Competition affects the contract offered to the agent through two channels. On the one hand, a higher level of competition increases the marginal return (in terms of an increased market share) to cost-cutting activities or productivity improvements (for instance if the elasticity of substitution between goods is higher under higher competition) and therefore the contract should provide steeper incentives to induce the manager to exert more effort. On the other hand a higher level of competition reduces the average profits of the firm for a given share of the market. For this reason firms

\footnotetext{
${ }^{5}$ The paper the unexpected appreciation of the pound in 1996 as a quasi-natural experiment to assess the differential impact of this shock on UK firms that were relatively exposed to it (with high openness to trade) with respect to firms that were relatively shielded from it (low trade openness). This provides difference in differences estimates of the both level and the slope of compensation.
} 
should make their incentive contracts flatter under more competition. Overall, the effect of an increase in competition is ambiguous.

Raith (2003), by allowing entry and exit of firms, eliminates the ambiguity. Endogenous exit guarantees that the first effect dominates, because profits do not drop like in Schmidt (1997). Competition leads to steeper incentives due to more profitable market stealing activities.

A related stream of literature explores the role of competition and its impact on information in relation to managerial incentives. Hart (1983) assumes that the role of competition is to tie the actions of managers more closely to the rest of the market and obtains that increased competition reduces managerial slack. Scharfstein (1988) shows that this result is very sensitive to the assumptions made, and Hermalin (1992) frames this result in a more general setting. In these papers the increase in competition is modelled as an increase in market transparency and therefore in the intensity of agency problems, whereas in Raith (2003) and Schmidt (1997) the effect is induced by changes in the profit distribution and the implied returns to effort.

Competition may also increase bankruptcy risk which, if there is a cost to managers losing their job, raises implicit incentives, thus reducing the need for explicit ones. This would reduce the slope of performance contracts. Changes in that slope may also occur if managers extract rents from their firms. Bebchuk, Fried and Walker (2002) explore the evidence in the existing literature for rent extracting activities in managerial compensation. They find a number of puzzles that cannot be explained using the standard principal agent theory but could be consistent with rent extraction explanations. ${ }^{6}$

Finally, it is important to note that the fixed component of pay may also be used to provide incentives. The efficiency wages theory argues that salaries should have a discipline effect if the fear of losing their job can discipline managers. This discipline effect will be larger the larger the fixed pay that they receive. To capture these effects, not only do we measure the interaction of the slope of the compensation packages with the competition measures, but also the effect of competition on the fixed component of pay.

Given the above, and the difficulty in disentangling the different simultaneous channels at work, our objective is to have a clear measure of the total effect of a change in competition on the fixed and the variable components of pay.

\footnotetext{
${ }^{6}$ In principle one could expect that if executives are risk averse, most of the rent extraction activities would be done through the fixed part of the compensation. However, for "camouflage" reasons we may also observe some rent extraction in the variable part of compensation. Bertrand and Mullainathan (2001) calculate a measure of "pay for luck" associated with rent extraction activities on the performance based component of executive compensation packages. They find positive rent extraction on the variable component and that this pay for luck is more intense in firms with bad governance.
} 


\section{Data and identification strategy}

Throughout the analysis we use the Standard \& Poor's Execucomp dataset. This is a panel dataset that covers the top five executives (ranked by salary and bonus) of all the firms included in the Standard \& Poor's 1500 index. We use yearly data from 1992 to $2002 .^{7}$ It records exhaustive data on executive compensation schemes as well as some individual characteristics. ${ }^{8}$ The individual level data on compensation includes yearly wage, bonus, stock options and other compensation. The data also contain information on firm characteristics and performance such as total assets, sales and shareholders value among others. The full sample for the basic specification and all years has 29,445 observations that correspond to 6,851 firm-executive pairs.

In the empirical analysis, we first analyze the evolution of pay structures. Then, we use two different specifications to compute changes in performance related pay. The first estimates sensitivities directly from the data, while the second exploits the fact that the sensitivity of the value of stock option grants to changes in firm value can be explicitly calculated. But before presenting the specifications and the source of identification it is important to discuss the deregulations and to what extent they can be interpreted as an increase in product market competition. ${ }^{9}$

\subsection{Two quasi-natural experiments: financial deregulation in the 90s}

The decade of the 1990s is thought of as a major deregulation period for the financial sector in the United States. Two major acts were implemented that were designed to foster competition.

The first one was the 1994 Riegle-Neal Interstate Banking and Branching Efficiency Act that eliminated two previous amendments that prohibited interstate banking. It implied that all commercial banks were allowed to own and operate branches in different states.

\footnotetext{
${ }^{7}$ The index includes firms in the S\&P 500 , S\&P MidCap 400, and S\&P SmallCap 600 Indices so it represents a stratified sample of quoted firms of all sizes.

${ }^{8}$ We control for individual unobserved heterogeneity in all specifications. Given that, individual characteristics such as age and tenure are only available for a very limited number of observations, and the criteria of selection are not clear, we decided not to use them as controls.

${ }^{9}$ Unfortunately there is no unique measure for product market competition. The use concentration ratios or Herfindahl indices can be subject to a number of criticisms. First, concentration is a very imperfect measure of the competitiveness of the sector if the definition of the relevant market is unclear. Second, standard competition models yield sometimes ambiguous results with respect to competition and concentration. Finally, concentration may be a response to the way in which compensation is set in the sector and hence be endogenous, or it may be correlated with some omitted variable. Deregulations are in principle not concerned with these criticisms.
} 
Prior to that, there were restrictions for banks to operate across borders, although during the 80 s reciprocal agreements were signed between some states. Several papers explore how these previous bilateral deregulation agreements affected bank performance and implied an increase in competitive pressure for banks in deregulated states. ${ }^{10}$

The 1994 Riegle-Neal Act (RNA) generated a nationwide lowering of entry barriers. For banks that already operated in states with some deregulation agreements, the RNA meant that they could now also operate in states that had not previously agreed to lower their barriers to entry, experiencing an increase in their potential market. For banks operating in states that had not deregulated previously the RNA meant, in addition to the enlargement of the relevant market, an increase in the number of potential competitors in the form of new entrants from other states. Both effects can be seen as an increase in competitive pressure. $^{11}$

Dick (2006) provides evidence on indicators that suggest an increase in competition in banking following the RNA. After the RNA, the total number of banks operating in the US decreased, however, the number of branches per person increased. The average number of banks operating at the state level grew significantly, as well as the average number of states in which a bank operates. This shows that at the relevant market dimension competition increased. It also shows that the RNA changed the competitive environment of banks that operated in relatively closed states before and faced an increase in external competitors, but also on banks that already operated interstate and experienced a significant increase in their potential market size. ${ }^{12}$ The effects on more qualitative dimensions such as the number of

\footnotetext{
${ }^{10}$ Stiroh and Strahan (2003) show that deregulation led to a reallocation of assets that moved towards more efficient banks. After deregulation, relative performance became a much better predictor of future market share. It also changed the exit dynamics of the banking sector leading to a higher rate of exit. These results are consistent with the view that deregulation can be seen as a decrease in barriers to entry and a subsequent increase in competition. Furthermore deregulation lead to reductions in costs and prices of banking services (Jayaratne and Strahan, 1998) and an increase in the growth rates of banks (Jayaratne and Strahan, 1996). De Young et al. (1998) show how entry in deregulated states lead to a decrease in cost efficiency of small urban banks in the short run but generated cost efficiency gains in the long run (six or more years). Nichols and Hendrickson (1997) show the impact of previous deregulation waves from 1929 to 1989 using Canadian banks as a benchmark for US reforms and vice versa. The freedom to establish new branches seems to have contributed to higher levels of efficiency.

${ }^{11}$ In our empirical specification, earlier differences across states will be differenced out, and the differencein-differences coefficient will capture the average effect of the increase in competitive pressure across firms. While it would be useful to have a measure of the extent of the increase in competitive pressure by state (among other things it would possibly increase the power of our estimates), this is not trivial to obtain in practice.

${ }^{12}$ Following Schmidt (1997), Raith (2003) or Vives (2004) one of the driving forces behind an increase in the sensitivity of pay to performance is the increase of the sensitivity of profits to efficiency gains due to increased market size or price elasticity of demand. This argument applies therefore both to banks that
} 
ATMs, operating costs and spreads are also suggestive of an increase in competition.

This is the first natural experiment used. We use two different specifications for it, in the first one (called the 1994 specification in the rest of the paper) uses the year the Act was passed as the turning period for the experiment because that is when banks expecting the deregulation to start operating in the future may have re-optimized their employment and pay strategies. The second one (called the 1994b specification in the rest of the paper) uses the effective dates of passing of the Act by state as in Dick (2006).

In the first specification (1994) we compare the years before 1994 (period 1992-1994) to those after 1994 (1995-1998). In the second one (1994b) the passing of the law differs by state ranging from 1994 to 1997. This is possible because different states passed the law at different times, so we can create a treatment variable for each bank depending on their reported location, this is specification 1994b. The treated group are the executives in the banking sector and the control group are the executives in the rest of the financial services sectors. Unfortunately, given that all commercial banks experienced the same deregulation it is not possible to use as control group another set of banks in the 1994 specification. However the 1994b specification partially does this, as in a given year some banks are considered as treated and some as not treated depending on the state in which they operate. For these two specifications the rest of the financial sector is the closest comparison group and a relevant labor market for executives in the commercial banking sector. $^{13}$

The second major change in the financial industry was brought about in 1999 with the Gramm-Leach-Bliley Act (GLBA) also known as the financial services modernization act. This repealed previous legislation (dating from the great Depression in the 1930s) that imposed barriers separating traditional banking, insurance and securities underwriting into three distinct industries which in practice meant that banks and investment firms were not competing with each other.

The perception that the GLBA would change the market structure of the financial sector can be seen in the share price reaction of the affected firms. Carow and Heron (2002) find that there was a significant price reaction on the stocks of firms that were involved in the deregulation. Firms belonging to major sectors that were likely to increase their target markets (insurance companies and investment banks) experienced positive abnormal returns while more specialized firms that could see their narrow business niches under threat (thrifts operated in relatively closed and open states before the RNA.

${ }^{13}$ An interesting feature of executive labor markets is that they do not coincide with the product market to which they belong. For example in Execucomp, about $2 / 3$ of the employment transitions between different firms are also between different (2 digit SIC) sectors. 
and finance companies) experienced abnormal negative returns. Foreign banks that could be previously benefiting to some extent from their ability to perform universal banking through their foreign branches also experienced abnormal negative returns. On top of this, large institutions seemed to have larger positive abnormal returns (or smaller negative ones). However, in principle, it is unclear that the GLBA benefited only larger companies. In fact by 2001 the firms that had achieved the status of Financial Holding Company (necessary to benefit from the act) concentrated on two different types of banks: first, the top tier bank holdings that were already trying to overcome the existing regulation and trying to be as "universal" as possible within the previous regulatory restrictions; and second, relatively small banks that were highly capitalized and healthy, but had no opportunity to expand within the previous regulation (Santomero, 2001). Our second test period are therefore the years between 1995-1999 versus 2000-2002. The treated group are the executives in the financial services sector and the control group contains executives in the rest of the services sectors in the economy.

The deregulations can therefore potentially be interpreted as increases in competition. However, the question remains as to what extent they can be seen as exogenous shocks. A potential concern in interpreting these deregulations as exogenous shocks to competition is to what extent they were anticipated by the industry and therefore may have started to have an effect prior to the deregulation year. On the one hand, if shareholders in the banking or financial services expected the deregulation to occur, then compensation contracts may have been changing prior to the deregulation date and the coefficients would under-estimate the impact of the deregulation. On the other had, if the deregulations were not truly exogenous but rather a reaction of regulators to changes in the industry, then the estimated coefficients could not be conclusively interpreted as causal.

To assess to what extent the previous caveats may be true, in Appendix 1 we test for the presence of differential pre-existing trends in performance-pay sensitivities for the deregulated and the non-deregulated sectors. The absence of such trends would lend credibility to the identifying assumption that the deregulation was an exogenous and sharp shock to product markets. We run regressions to evaluate this hypothesis by interacting the treatment variable with year dummies (see expressions 3 and 4 below), and find that prior to the 1999 deregulation there were no significant differential trends in contract slopes between deregulated and non-deregulated sectors. The evidence for the 1994 deregulation is slightly more mixed, suggesting that there might have been some degree of anticipation, but this trend is based on two coefficients only so it is hard to judge. 


\section{Specifications and Results}

We now turn to discuss the specifications and present the results. Section 4.1 starts with some general trends in executive pay in the deregulated sectors, Section 4.2 presents the effect of both deregulations on different magnitudes of executive pay, Section 4.3 shows the results regarding the effects of the experiments on fixed and variable pay. Finally, Section 4.4 concentrates on how the sensitivity of the stock option packages granted to executives changed after the deregulation experiences.

\subsection{General trends}

Table 2 shows the general trends in total pay (columns one and two), estimated fixed and variable pay (columns three and four), and the share of the value of options granted over total compensation (columns five and six), during the whole sample period for our treatment groups (commercial banks and the financial services sector). These are just descriptive of the overall change in compensation structures in our treatment groups, before presenting the full difference-in-differences results using the deregulations. For each treated group, we regress a measure of compensation $W_{i f j t}$ on a linear trend, its interaction with our measure of performance $P \operatorname{erf}_{f j t}$, a set of controls $X_{i f j t}^{z}$, time dummies $d_{t}$ and firm specific individual fixed effects $\eta_{i f}$.

$\ln \left(W_{i f j t}\right)=a_{0}+\theta$ trend $_{t}+\beta_{0} \ln \left(P \operatorname{erf}_{f j t}\right)+\beta_{1} \ln \left(P \operatorname{erf}_{f j t}\right) *$ trend $_{t}+\sum a_{z} X_{i f j t}^{z}+\eta_{i f}+d_{t}+\epsilon_{i t}$

The standard errors in all specifications are clustered at the four digit industry level to account for potential serial correlation. We use the natural logarithm of firm performance measured as total shareholders value, and defined as the previous total value of the firm multiplied by the total gross returns of holding the stock during the relevant period including the reinvestment of dividends. ${ }^{14}$ Assuming markets are efficient, shareholders value represents the total discounted value of the future profits of the firm. Given the fixed effects specification and the fact that both the dependent variable and performance are in natural logarithms, the coefficients $\beta_{0}, \beta_{1}$ measure the percentage change in pay associated to a percentage change in shareholders value. This specification has the advantage of being less sensitive to outliers than one in levels and the estimated coefficients can be directly read

\footnotetext{
${ }^{14}$ This is equivalent to measuring firm performance as the logarithm of the total market value of the firm, when this value includes the reinvestment of dividends and excludes mergers, share buyouts, spin-offs, and seasoned equity offerings
} 
off as elasticities. ${ }^{15} \epsilon_{i f j t}$ is a white noise

Columns one to four use total compensation as the dependent variable, defined as the sum of salary, bonus, total value of restricted stock granted, total value of stock options granted (using the standard Black and Scholes formula), long term incentive payouts, and other annual payments (this is execucomp variable TDC1). Columns one and two impose that $\beta_{0}=0$ and $\beta_{1}=0$ to reflect the overall trend in total compensation in the deregulated sectors. The results show that the average annual increase in real terms of total compensation for Commercial Banks and Financial Services was 15 percent and 14 percent respectively. The composition of this increase is shown in columns three and four. By introducing performance explicitly, the regression captures the sensitivity of pay to performance in $\beta_{0}$ and the trend in this sensitivity in $\beta_{1}$, while $\theta$ now captures the trend in the fixed component of pay that is unrelated to firm performance. The results reveal that fixed pay decreased by 3.2 percent and 2.6 percent on average respectively while the dollar sensitivity of performance to pay, increased between 2.2 percent and 1.4 percent per year. It is important to note that these are estimated sensitivities and therefore they also capture the sensitivity to performance of the parts of pay that are considered traditionally fixed. As an example, if promotions associated with higher salaries became more contingent on contemporaneous performance during this period, even the fixed salary part of pay would contribute to the observed results. Columns five and six show an increasing trend in the share of the value of stock options granted over total compensation of about 2.8 percent and 2.1 percent per year in each sector.

Overall the general trends show an increase in total pay due mainly to an increase in contingent pay and in spite of some reduction in fixed pay. To understand what part of these trends could be due to the general deregulation of the sector, in the next sections we perform difference-in-differences estimates using the two deregulation experiments.

\subsection{Total pay}

Table 3 shows the effect of the two deregulations on different magnitudes of total pay in the deregulated sectors relative to non-deregulated ones.

To assess the effect of the deregulations on total compensation and on performance related pay, we first define the variable treat $_{j}$ that takes value one for the treated sectors and zero for the control group. Firms are classified according to their primary SIC code. ${ }^{16}$

\footnotetext{
${ }^{15}$ It is also similar to the specifications in Bertrand and Mullainathan (2001), Rosen (1992) and Murphy (1986) among others.

${ }^{16}$ Firms might operate in different industries which might include misclassification. In terms of our experiments, before 1999 it was not possible for a commercial bank to perform other financial services so this
} 
For the 1994 deregulation the treated sector is the banking sector (SIC code at two digits is 60 ) and the comparison group is the rest of the financial services sector(SIC 60 to 69). For 1999, the treatment group is made by firms in sectors with SIC codes 60 to 64 and 67, and the control group are the other services sectors in the economy. We then define the variable post $_{t}$ that takes value one in the treatment period and zero otherwise (post 1994 and post 1999 are defined for all firms using year information only, while for specification 1994b, we define the treatment period for each bank using the actual year of passing the law by the state). To avoid the interference between both natural experiments we use the period 1992-1994 as the control sample for the first experiment and 1995-1998 as the treatment period. For 1999 we use 1995-1999 as the control sample and 2000-2002 as the treatment period. We use information on the fiscal year by firm, and the month where the laws were passed, so the first period where post $_{t}=1$ is the one in which the full fiscal year happens after the deregulation. Our main variable of interest is the variable $F I N_{j t}$ which takes value one for the treated sectors after the deregulation and zero otherwise. Therefore $F I N_{j t}$ is the interaction of treat $_{j}$ and post $_{t}$.

Then, total compensation for executive $i$, in firm $f$, in sector $j$, in year $t$, can be written as:

$$
\ln \left(W_{i f j t}\right)=a_{0}+a_{1} F I N_{j t}+\sum a_{z} X_{i f j t}^{z}+\eta_{i f}+d_{t}+\epsilon_{i f j t}
$$

The control variables $X_{\text {ifjt }}$ include the log of assets to control for firm size, a dummy variable that takes value one if the executive has just joined the firm to control for the impact of starting packages, and position dummies that include a dummy variable that takes value one if the executive is the CEO of the firm and hierarchy dummies that control for the hierarchical position of the executive in the firm, measured as their ranking in salary and bonus (highest paid, second highest paid,..., fifth or lower). It also includes time dummies $d_{t}$ and firm specific individual fixed effects $\eta_{i f} . \epsilon_{i f j t}$ is a white noise. ${ }^{17}$ The standard errors in all specifications are clustered at the four digit industry level to account for potential serial correlation.

The dependent variable $W_{i f j t}$ is one of two compensation measures. We first use cash compensation (salary plus bonus). Then we use a more comprehensive measure, Total

is not a concern for the 1994 experiment or the first part of the 1999 experiment. After 1999 some commercial banks, insurance companies and investment banks start operating in each others sectors, but since the treated category is financial services, they should not change. Firms might, on the other hand, report a primary SIC code in banking or finance but operate also in another sector. To the extent that this would induce measurement error it would tend to bias our results to zero.

${ }^{17}$ The variables treat $_{j}$ and post $_{t}$ are implicitly included in all the regressions by introducing year and individual dummies. Furthermore, we interact them in some specification to provide a full difference in differences structure whenever we have variables that interact with $F I N_{j t}$. (See expression 2) 
Compensation, that is defined as the sum of salary, bonus, total value of restricted stock granted, total value of stock options granted (using the standard Black and Scholes formula), long term incentive payouts, and other annual payments (this is execucomp variable TDC1). All the monetary values are in constant 1996 dollars.

Since all regressions include firm-specific individual fixed effects $\eta_{i f}$, an executive that changes firm is considered as a different individual. Therefore the identification comes purely from a within-individual change in the competitive environment, while the individual stays in the same firm. Even though the variation in competition is at the sector level, if one omitted individual fixed effects, the fact that individuals with different permanent unobserved component of wages (say different ability levels, or risk aversion etc.) sort themselves into sectors with different degrees of competition can potentially bias our estimates. Given that no individual changes sector in our specification, $\eta_{i f}$ captures also the sector and firm effects. The inclusion of these firm-specific individual fixed effects $\eta_{i f}$ and year dummies $d_{t}$, produces a difference-in-differences estimate of the effect of the deregulations on total pay where pre-existing differences across industries are netted out: $a_{1}$ captures how much total pay changed in deregulated sectors relative to non-deregulated sectors after the deregulation.

The results of this specification are shown in table in table 3, and are in general not statistically significant, showing that most of the effect of the deregulation might have been on the composition of pay and not quite on the size of total pay. However, the point estimates are revealing of the compositional change in executive pay following the deregulations. While the effect of both deregulations on salary plus bonus is small or negative (columns one, three and five), the effect is positive for the more inclusive pay categories (columns two, four and six).

Since these are difference-in-differences specifications (all include year and firm-specific individual dummies), the coefficients on FIN99, FIN94b and FIN94 do not capture any preexisting differences between the treated and the non treated sectors, nor the general time evolution of pay.

A number of earlier papers have studied the characteristics of compensation in banking relative to other industries. Houston and James (1995) show that average CEO cash compensation and the fraction of compensation that is held in stock options is lower in banks than in other industries, but overall performance pay sensitivities are very similar. John and Qian (2003) on more recent data find that performance pay sensitivities are lower in banking than in other industries. In any case, our regressions control for pre-existing differences across industries, such that any potential initial heterogeneity across industries is differenced out. 
These results are already suggestive of a shift from fixed to variable pay induced by the deregulations. Section 4.3 performs a more detailed analysis and estimates explicitly changes in the estimated fixed and variable components of executive pay.

\subsection{Fixed pay and performance-related pay sensitivities}

Next, to assess to what extent these changes came from changes in the fixed or the variable component of pay, we estimate how compensation changes with firm performance, $\operatorname{Per} f_{f j t}$ :

$$
\begin{aligned}
\ln \left(W_{i f j t}\right)= & a_{0}+a_{1} F I N_{j t}+b_{0} \ln \left(P \operatorname{erf}_{f j t}\right)+b_{1} F I N_{j t} \ln \left(P \operatorname{erf}_{f j t}\right)+ \\
& b_{2} \text { treat }_{j} \ln \left(P \operatorname{erf}_{f j t}\right)+b_{3} \text { post }_{t} \ln \left(P \operatorname{erf}_{f j t}\right)+\sum a_{z} X_{i f j t}^{z}+\eta_{i f}+d_{t}+\epsilon_{i t}(3)
\end{aligned}
$$

The control variables $X_{i f j t}^{z}$ are the same as in the previous section. We use the natural logarithm of firm performance measured as shareholders value, and defined as above. Here again, given the fixed effects specification and the fact that both the dependent variable and performance are in natural logarithms, the coefficients $b_{0}, b_{1}, b_{2}, b_{3}$ measure the percentage change in pay associated to a percentage change in shareholders value.

In this specification, $a_{1}$ is the difference-in-differences estimate of the change in the fixed component of pay following the deregulation. $b_{0}$ measures the basic sensitivity of pay to performance in the sample (the slope of the performance pay contract). To provide a full difference-in-differences estimate one must take into account that the sensitivity of pay to performance might have been different for deregulated and non-deregulated sectors throughout the sample period, or that it may have increased for all sectors after the deregulation. $b_{2}$ captures the fact that the deregulated sectors might have had different sensitivities throughout the sample period and $b_{3}$ captures whether after deregulation all sectors had a change in their contract sensitivities. Therefore $b_{1}$ captures the change in the slope following the deregulation in deregulated sectors relative to non-deregulated ones.

This last specification provides a difference-in-differences estimator of the effect of competition on both the level and the slope of pay to performance. It builds on standard estimations and measures of performance pay sensitivities used in the literature, such that one can benchmark the results against stylized facts (Murphy, 1999), and it provides a comprehensive estimate of the structure of compensation. As usual, a maintained assumption of the difference-in-difference specification is the absence of a bias that affects differently deregulated and non-deregulated firms after the deregulation. Notice also that if performance leads to a promotion (and a raise) within the firm, this will be captured by the performance coefficient along with standard variable compensation. Finally, we also perform a number of robustness checks on this basic specification. 
Table 4 presents the results associated with the 1994 deregulation experiment. It shows results using the year of the announcement as the treatment year for all commercial banks (1994 specification), and the results using the effective date when the Riegle-Neal bill was adopted in each state (1994b specification). In principle it is unclear whether one specification should be more relevant than the other, as it could be the case that firms might have realigned their incentive schemes in 1994 when they already anticipated that their state was eventually going to adopt the interstate branching deregulation, rather than the date of adoption.

Columns one and two show that deregulated sectors decreased the fixed component of cash compensation defined as salary plus bonus (negative coefficient on the "FIN94" variable) and, at the same time increased its sensitivity to performance (positive coefficient on "FIN94*Performance"). The base sensitivity of cash compensation to performance (coefficient on the "Performance" variable) shows an 8 percent increase in pay if the executive increases the value of the firm by 100 percent. For deregulated sectors, this percentage increased by an additional 3.7 percent relative to non deregulated sectors with the 1994 specification, and 7.6 percent in the 1994b specification.

Columns $2 \mathrm{a}$ and $2 \mathrm{~b}$ replicate this basic specification for total compensation, with statistically insignificant results for the effect of the deregulation in the 1994 specification. The 1994b specification (columns 2b, 3b and 4b) generally yields results much stronger in size and statistically more significant showing that the adoption dates by state may be closer to the moment when banks adjusted their compensation than the actual passing of the bill. The increase in performance related pay for the total compensation specifications ranges from 4.7 percent to 6.5 percent in the 1994b specification, which is quite a large effect considering that the average performance related pay in the sample for non treated firms ranges from 14 percent to 16 percent. The reduction in fixed pay is also substantial and 41 percent to 55 percent larger than in non-deregulated firms. Overall, the results show that deregulated firms substituted fixed pay with more performance related pay after the 1994 deregulation.

The last four columns check the robustness of the main specifications. The first check is to use two different measures of pay as explained in this section, one is very restrictive and includes only salary and bonus while the other one is the most comprehensive available measure of pay. Secondly, we allow for the possibility of Relative Performance Evaluation (RPE). To that end, we introduce as a control the average stock market returns in the sector and also interact it with the deregulation variables (the variable "Sector Performance" is interacted with FIN94; as well as with Treated94 and Post94 which are unreported). If firms use RPE to set compensation contracts then the sector returns coefficient should enter the 
regression with a negative sign, and its difference with the estimated sensitivity (the coefficient on the performance variable) is the RPE estimate. We also assess how RPE changed following the deregulation. Columns $3 \mathrm{a}$ and $3 \mathrm{~b}$ show the results. If actual compensation packages contain relative performance evaluation measures, we may have been capturing the change in this part of pay as a change in the sensitivity of own performance. Aggarwal and Samwick (1999) argue that principals used RPE to induce a given type of competitive behavior. Here the channel exploited goes from exogenous changes in competition in a given sector to performance contracts, hence that type of mechanism is unlikely to be present. In fact the inclusion of these extra variables does not change the results and it yields also non significant results on both the own and sector performance variables.

Finally, instead of including firm-specific individual fixed effects we use standard individual fixed effects (such that the individual keeps his identity after changing firms) and sector dummies. Identifying the coefficients from movers regression increases the variability of pay and performance and should therefore increase the precision of the estimates. On the other hand, the identified effects are a mix of the changes in existing pay agreements in deregulated firms and new agreements signed by executives switching firms. This is done in columns $4 \mathrm{a}$ and $4 \mathrm{~b}$, and yields statistically significant results that match qualitatively earlier ones.

Table 5 shows the results associated with the 1999 deregulation experiment. Column one estimates the sensitivity of cash compensation to firm performance and shows a statistically insignificant effect of the 1999 deregulation on that sensitivity. Column two in turn, shows a substantial effect of the deregulation on the sensitivity of total pay to firm performance. The baseline elasticity (coefficient associated with the variable "Performance") for both deregulated and non-deregulated is around 12 percent. Deregulation increased the performance-pay sensitivity an additional 5 percent of total pay for every 100 percent of increased shareholders wealth. So relative to the baseline sensitivity of 14 percent, deregulation lead to an increase in the sensitivity of executive pay to increases in shareholders wealth of 35 percent more with respect to the change in sensitivity experienced by non-deregulated sectors.

Two other interesting results are worth mentioning in column two. First, the coefficient associated with the variable Post99*Performance is negative and statistically significant. This is due to the fact that the sensitivity of performance-related-pay fell from year 2000 . The coefficient associated to the experiment is slightly larger, so a more accurate interpretation of the results is that while the performance-pay sensitivity of the rest of the sectors went down after year 2000, the deregulated sectors maintained their previous sensitivity and even increased it slightly. Second, the coefficient associated with the variable FIN99 is 
negative and statistically significant, indicating a reduction in the fixed component of pay.

The results in column three show that the effect is robust to allowing for relative performance evaluation. Regarding the use of RPE, the coefficient on sector performance that should be negative in the presence relative performance evaluation - is statistically insignificant. The interaction with the experiment is positive and marginally statistically significant. This is an interesting result for which there is no clear explanation in the literature but it is not a very strong one and exploring it is beyond the scope of this paper.

Overall, we can conclude that both the 1999 and the 1994 deregulations lead to executive pay packages that had a lower fixed component and a larger performance based component relative to the sectors that were not deregulated. These results are consistent with the predictions of Raith (2003); or in the spirit of Schmidt (1997) one should conclude that the effect associated with the additional elasticity of returns to managerial effort dominates the implicit discipline imposed by higher competition.

\subsection{Stock option grants sensitivity}

In the previous section (and in most of the existing literature) options are evaluated at their value at inception and treated as a cash reward. This approach is simple and probably correct if executives have a portfolio of the firm stocks and stock options that they can rebalance to keep constant their exposure to changes in the share price. However, if this rebalancing is not feasible, options are in themselves an instrument to provide incentives, and one should consider them as a long term contingent payment. However, an alternative measure of the sensitivity of executive compensation to changes in shareholders wealth can be explicitly calculated using a formula and not an econometric estimation: this is the sensitivity of the stock option packages granted. As a whole, option grants represent a very significant part of total compensation and an even higher share of its contingent part. This section emphasizes the dual role of stock options in executive compensation: on the one hand option grants have an intrinsic value, and could be seen as a reward to past performance. On the other hand options provide incentives to improve future performance.

The 'delta' of each option measures the sensitivity of the value of that option to changes in share price. We can use this information to calculate the sensitivity of a particular stock option grant to changes in shareholder value. Given that stock option grants have become one of the main sources of contingent remuneration for executives these are very relevant measures to see the evolution of performance-related-pay with competition.

We measure the sensitivity of the value of the option packages granted to the executive to changes in the value of the firm, using the measure introduced by Yermack (1995). It 
consists in multiplying the sensitivity of the price of each option to the share price (delta) by the percentage of total shares outstanding that the new issue of options represents. In practice, the sensitivity of executive pay to changes in shareholders wealth associated to each option issue is measured as delta. $\frac{\text { Number of shares represented by option award }}{\text { Number of shares outstanding }}{ }^{18}$ Then we add the sensitivity of the different issues in a particular period to get the total sensitivity measure for that year. The measure is expressed in extra dollars of compensation for every 1000 extra dollars of shareholders wealth.

In the data, the total number of grants is 82,912 and the weighted average delta of all grants is 0.77 . The total amount of year-executive observations that have at least one grant is 19,731 and the median sensitivity across individuals of all the granted packages is 37.6 cents per 1000 extra dollars of shareholders value.

To identify whether the change in competition in our experiments altered the sensitivity of the packages of options granted we run the following regression

$$
\text { OptionGrantSensitivity }_{i f j t}=\alpha+\beta F I N_{j t}+d_{t}+d_{j}+\eta_{i f}+\varepsilon_{i f j t}
$$

This is a standard difference-in-differences estimation in which $\beta$ measures the differential change in sensitivity in sectors subject to a deregulation with respect to the sectors that were not. The inclusion of year, $d_{t}$, firm-specific individual fixed effects $\eta_{i f}$, and sector, $d_{j}$, dummies guarantees that we are not just capturing a general change after the deregulations or a compositional effect. Note that given that the measure is a performance-pay sensitivity in itself, we need not interact the deregulation dummy with the performance measure, this reduces any potential multicollinearity problems and allows us to saturate the specification further. In particular, we control for year by year changes in the sensitivity of stock option packages and include controls for sector specific time trends.

Given that we want to measure the change in the compensation policy of the firm after the deregulation, most of the relevant information relative to options is contained in the new option grants. If firms want to increase (decrease) the sensitivity of pay to performance of their executives they can increase (decrease) the amount of options granted and also use options with higher (lower) delta. However, ideally one would also want to measure the overall sensitivity of the stock option holdings. This measure cannot be calculated with the

\footnotetext{
${ }^{18}$ We use exactly the same methodology as in Yermack (1995). The sensitivity is defined as delta $=\frac{\partial \text { Black Scholes Value }}{\partial \text { Share price }}$. The derivative of the black scholes value is calculated using the monthly volatility of the stock price over the last 60 months, the average dividend yield of the stock, and the risk free interest rate. The maturity of new option grants with missing information about their time to maturity is set to 10 years, as this is the most frequent maturity (Hall and Liebman 1998). The summary statistics of the delta measure are comparable with the ones obtained by Hartzell and Starks (2003) in a similar sample of Execucomp.
} 
data available in Execucomp ${ }^{19}$.

Table 6 shows how the stock option grant sensitivity changed following the two deregulations. Columns one and two correspond to the basic 1994 specification, the difference between them is that the specification in column 2 contains sector specific time trends as controls. The results in column one are marginally not statistically significant. Column 2 however strongly suggests that following the deregulation, commercial banking executives experienced an increase of 36 cents of additional option value per additional thousand dollars of shareholders value. Columns three and four show the results with respect to the 1994b experiment and again only the specification with sector specific time trends yields a statistically significant coefficient with an increase of 55 cents of additional option value per additional thousand dollars of shareholders value.

Columns five and six show the results of the 1999 experiment, in this case only the less saturated specification yields statistically significant results, with an increase of 37 cents per additional thousand dollars of firm value.

Overall, the results in Table 6 are consistent with the results in Section 4.3. Each approach has its own advantages: while the approach in Section 4.3 uses more comprehensive measures of pay, the approach in this section uses calculated and not estimated sensitivities. Given that both approaches are quite different and we reach similar conclusions both results reinforce each other.

\section{Conclusions}

The determinants of managerial compensation have received a lot of attention, but little is known about how these are affected by the degree of product market competition that firms face. The competitive environment generates implicit incentives that determine the design of compensation packages and hence alter the need for and magnitude of explicit incentives. In this paper we draw together the main theories explaining the impact of product market competition on compensation packages and empirically evaluate its effect.

We restrict the analysis to the financial sector and assess how two major deregulations, that we interpret as quasi-natural experiments for increases in product market competition, affected the level and structure of executive pay. Our results indicate that total pay stayed constant or marginally increased following the deregulations, but this moderate increase is reflecting strong differential trends in the fixed and variable components of pay. We

\footnotetext{
${ }^{19}$ See Hall and Liebman (1998) for an attempt to measure the overall option portfolio sensitivity. This calculation requires a large amount of data periods and relies on a set of assumptions to compensate for the lack of information on some aspects like which options are executed first.
} 
provide substantial evidence of a reduction in the fixed component of pay and an increase in the sensitivity of pay to performance, implying that as competition increases, managers are faced with steeper incentives to increase firm performance. This increased sensitivity is found when we compute the sensitivity of total compensation to firm performance explicitly, as well as when we use the sensitivity of stock option grants.

Therefore, the results indicate that both deregulations and the increase in competition they implied, lead to a higher reliance on performance related pay. It therefore provides a potential explanation for the trend over the past decades of an increased use of these compensation mechanisms. It also indicates that there may be an impact of competition on the dispersion of earnings in the economy if, as product markets become more competitive, performance-related pay contracts become more pervasive for all levels of workers. Direct tests of these issues are left for future research. 


\section{References}

[1] Aggarwal, Rajesh K.; Andrew A. Samwick (1999) Executive Compensation, Strategic Competition, and Relative Performance Evaluation: Theory and Evidence, Journal of Finance, Vol. 54 iss. 6, pp.1999-2043

[2] Bebchuk, Lucian Arye; Jesse M. Fried; David I. Walker (2002) Managerial Power and Rent Extraction in the Design of Executive Compensation, Harvard Law School DP 366

[3] Bertrand, Marianne; Sendhil Mullainathan (2001) Are CEOs Rewarded for Luck? The Ones Without Principals Are, The Quarterly Journal of Economics, Vol.116 iss. 3, pp.901-32

[4] Black, Sandra E.; Phillip E. Strahan (2001) The Division of Spoils: Rent Sharing and Discrimination in a Regulated Industry, The American Economic Review, Vol.91 iss.4, pp.814-831

[5] Carow, Kenneth A.; Randall A. Heron (2002) Capital Market Reactions to the Passage of the Financial Services Modernization Act of 1999. The Quarterly Review of Economics and Finance, Vol.42, pp.465-485

[6] Crawford, Anthony J.; John R. Ezell; James A. Miles (1995) Bank CEO PayPerformance Relations and the Effects of Deregulation, The Journal of Business, Vol. 68 iss. 2, pp. 231-256

[7] Cuñat, Vicente; Maria Guadalupe (2005) How Does Competition Shape Incentive Contracts? Journal of the European Economic Association, Vol. 3 iss. 4, pp. 1058-1082

[8] De Young, Robert; Iftekhar Hasan; Bruce Kirchoff (1998) The Impact of Out-of-State Entry on the Cost Efficiency of Local Commercial Banks, Journal of Economics and Business, Vol.50, pp.191-203

[9] Dick, Astrid A. (2006) Nationwide Branching and its Impact on Market Structure, Quality and Bank Performance The Journal of Business, Vol. 79 iss.2

[10] Hall, Brian J.; Jeffrey B. Liebman (1998) Are CEOs Really Paid Like Bureaucrats? Quarterly Journal of Economics, Vol.113, pp.653-691

[11] Hart, Oliver (1983) The Market Mechanism as an Incentive Scheme, Bell Journal of Economics, Vol.74, pp.366-682

[12] Hartzell, Jay C.; Laura T. Starks (2003) Institutional Investors and Executive Compensation, The Journal of Finance, Vol. 58 iss 6, pp.2351-2374

[13] Hermalin, Benjamin E. (1992) The Effects of Competition on Executive Behaviour The RAND Journal of Economics, Vol.23 iss.3, pp.350-365 
[14] Houston, Joel F. and James, Christopher (1995) CEO Compensation and Bank Risk: Is Compensation in Banking Structured to Promote Risk Taking?, Journal of Monetary Economics, Vol.36, pp.405-431

[15] Hubbard, Glenn R.; Darius Palia (1995) Executive pay and performance Evidence from the US banking industry, Journal of Financial Economics, Vol.38, pp.105-130

[16] Jayaratne, Jith; Philip E. Strahan; (1996) The Finance-Growth Nexus: Evidence from Bank Branch Deregulation. Quarterly Journal of Economics, Vol.111, pp.639-670

[17] Jayaratne, Jith; Philip E. Strahan; (1998) Entry Restrictions, Industry Evolution, and Dynamic Efficiency: Evidence from Commercial Banking. The Journal of Law and Economics, Vol.41, pp.239-273

[18] Joh, Sung Wook; (1999) Strategic Managerial Incentive Compensation in Japan: Relative Performance Evaluation and Product Market Collusion, Review of Economics and Statistics, Vol.81 iss.2, pp. 303-313

[19] Joskow, Paul L.; Nancy Rose; Andrea Shepard; John R. Meyer; Sam Peltzman; (1993) Regulatory Constraints on CEO Compensation Brookings Papers on Economic Activity. Microeconomics, Vol. 1993 iss.1, pp.1-72

[20] Joskow Paul L.; Nancy L. Rose; Catherine D. Wolfram; (1996) Political Constraints on Executive Compensation: Evidence from the Electric Utility Industry The RAND Journal of Economics, Vol. 27 iss.1, pp.165-182

[21] John, Kose; Qian, Yiming (2003) Incentive Features in CEO Compensation in the Banking Industry, Federal Reserve Bank of New York Economic Policy Review, Vol. 9 iss. 1, pp.109-121.

[22] Kedia, Simi (2006) Estimating Product Market Competition: Methodology and Application, Journal of Banking and Finance, vol. 30.

[23] Murphy, Kevin J. (1986) Incentives, Learning, and Compensation: A Theoretical and Empirical Investigation of Managerial Labor Markets, Rand Journal of Economics, Vol.17 iss.1, pp. 59-76

[24] Murphy, Kevin J, (1999) Executive Compensation, Handbook of labor economics. Volume 3B, pp.2485-2563, Handbooks in Economics, vol. 5. Amsterdam; New York and Oxford: Elsevier Science, North-Holland

[25] Murphy, Kevin J.; Zábojník, Ján (2004a) CEO Pay and Appointments: A MarketBased Explanation for Recent Trends', American Economic Review, American Economic Association, Vol. 94 iss.2, pp. 192-196.

[26] Murphy, Kevin J.; Zábojník, Ján (2004b) Managerial Capital and the Market for CEOs', Working Paper. 
[27] Nichols, Mark W.; Jill Hendrickson (1997) Profit Differential Between Canadian and U.S. Commercial Banks: The Role of Regulation, Journal of Economic History, Vol.57 iss.3, pp.674-696.

[28] Raith, Michael (2003) Competition, Risk and Managerial Incentives, American Economic Review, Vol. 93, pp. 1425-1436

[29] Rosen, Sherwin (1992) Contracts and the Market for Executives, in Lars Werin and Hans Wijkander (eds), Contract Economics, Oxford: Blackwell, chapter 7, pp.181-211.

[30] Santomero; Antony M. (2001) The Causes and Effects of Financial Modernization, Business Review Federal Reserve Bank of Philadelphia, Q04

[31] Scharfstein, David; (1988) Product-Market Competition and Managerial Slack The RAND Journal of Economics, Vol.19 iss., pp.147-155

[32] Schmidt, Klaus M. (1997) Managerial Incentives and Product Market Competition; Review of Economic Studies, Vol. 64 iss. 2, pp.191-213

[33] Stiroh, Kevin J and Philip E Strahan (2003) Competitive dynamics of deregulation: Evidence from U.S. banking, Journal of Money, Credit, and Banking, Vol. 35 iss.5, pp. $801-828$

[34] Vives, Xavier (2004) Innovation and Competitive Pressure, CEPR Discussion Paper, April, No. 4369

[35] Yermack, David (1995) Do corporations award CEO stock options effectively? Journal of Financial Economics, Vol.39, pp. 237-269 


\section{Tables}

\section{Table 1: Descriptive Statistics}

a. Sample period is 1995-2002 for 1999 sample and 1993-1999 for 1994 sample. Sectors included in 1999 experiment: all the services, the deregulated sector being the financial services (SIC 60 to 67). Sectors included in the 1994 experiment are only the financial services, the deregulated sector being Banking (SIC60).

b. All nominal variables are in 1996 US dollars.

c. Total Compensation equals the sum of salary, bonus, total value of restricted stock granted, total value of stock options granted (using Black and Scholes), long term incentive payouts, and other annual payments.

d. Performance is measured as total shareholders value, and defined as the previous total value of the firm multiplied by the total gross returns of holding the stock during the relevant period including the reinvestment of dividends. It is defined in million US dollars and we use its natural logarithm. Sector Performance is the average of $\ln$ (Performance) by two digit SIC code and year. Stock option grant sensitivity computed as in Yermack (1995).

e. New executives dummy is defined as executives that move into a deregulated firm after the deregulation from outside the firm.

\begin{tabular}{|c|c|c|c|c|}
\hline & \multicolumn{2}{|c|}{1999 Experiment sample } & \multicolumn{2}{|c|}{1994 Experiment sample } \\
\hline & Mean & Std. Dev. & Mean & Std. Dev. \\
\hline $\ln$ (Salary plus Bonus) (US dollars) & 12.96 & 0.973 & 13.10 & 0.97 \\
\hline $\ln$ (Total comp.) ( US dollars) & 13.95 & 1.22 & 13.8 & 1.07 \\
\hline $\ln$ (Performance) & 7.19 & 1.76 & 7.64 & 1.46 \\
\hline Stock option grants sensitivity (cents per 1000 US dollars) & 12 & 32 & 5.7 & 22 \\
\hline $\ln$ (Sector Performance) & 7.27 & 0.69 & 7.72 & 0.48 \\
\hline New executives, percentage & 2.4 & & 11.8 & \\
\hline CEO, percentage & 14.3 & & 12.0 & \\
\hline
\end{tabular}




\section{Table 2: General Trends}

The dependent variable in columns one to four is the log of total compensation. The dependent variable in columns five and six is the ratio of the value of options granted on a given year over total pay.

$\ln$ (Performance) is measured as the log of shareholder wealth. Options Granted/Total Pay is the total value (using Black Scholes pricing ) of the stock options granted over total compensation. Trend is a linear yearly trend. All regressions contain firm specific individual effects, therefore account for sector, firm and individual permanent unobserved heterogeneity. Std errors in brackets are clustered at the four digit SIC level

Notes to Table 1 for a definition of all other variables and exact samples.

\begin{tabular}{|c|c|c|c|c|c|c|}
\hline & \multicolumn{2}{|c|}{$\ln ($ Total Comp.) } & \multirow{2}{*}{\multicolumn{2}{|c|}{$\begin{array}{l}\ln (\text { Total Comp.) } \\
\text { Pay Composition }\end{array}$}} & \multicolumn{2}{|c|}{ Options Granted/Total Pay } \\
\hline & \multirow{3}{*}{$\begin{array}{l}\text { Commercial } \\
\text { Banks }\end{array}$} & \multirow{3}{*}{$\begin{array}{l}\text { Financial } \\
\text { Services }\end{array}$} & & & & \\
\hline & & & \multirow{2}{*}{$\begin{array}{l}\text { Commercial } \\
\text { Banks }\end{array}$} & \multirow{2}{*}{$\begin{array}{l}\text { Financial } \\
\text { Services }\end{array}$} & \multirow{2}{*}{$\begin{array}{l}\text { Commercial } \\
\text { Banks }\end{array}$} & \multirow{2}{*}{$\begin{array}{l}\text { Financial } \\
\text { Services }\end{array}$} \\
\hline & & & & & & \\
\hline & 1 & 2 & 3 & 4 & 5 & 6 \\
\hline \multirow[t]{2}{*}{ Trend } & $0.1505^{* * *}$ & $0.1359 * * *$ & $-0.0322^{*}$ & $0.0258^{*}$ & $0.0285^{* * *}$ & $0.0218^{* * *}$ \\
\hline & {$[0.0032]$} & {$[0.0026]$} & {$[0.0187]$} & {$[0.0132]$} & {$[0.0011]$} & {$[0.0009]$} \\
\hline \multirow[t]{2}{*}{ TrendXln(Performance) } & & & $0.0224^{* * *}$ & $0.0140 * * *$ & & \\
\hline & & & {$[0.0023]$} & {$[0.0017]$} & & \\
\hline $\ln ($ Performance $)$ & & & -0.0081 & $0.0459^{* * *}$ & & \\
\hline \multirow{3}{*}{$\begin{array}{r}\text { Individual FE, firm specific? } \\
\text { Observations }\end{array}$} & yes & yes & yes & yes & yes & yes \\
\hline & 5663 & 12686 & 5663 & 12686 & 5663 & 12686 \\
\hline & 0.339 & 0.225 & 0.384 & 0.267 & 0.134 & 0.061 \\
\hline
\end{tabular}

* significant at $10 \% ; * *$ significant at $5 \% ; * * *$ significant at $1 \%$ 


\section{Table 3: Effect of Deregulation on Total Pay}

FIN94 takes value 1 if the individual is in the banking sector after 1994, 0 otherwise. FIN94b takes value 1 if the individual is in the banking sector after the Riegle-Neal bill is passed in the sate where the bank is incorporated and zero otherwise. FIN99 takes value 1 if the individual is in the financial services sector after 1999, 0 otherwise. All regressions contain firm specific individual effects, therefore account for sector, firm and individual permanent unobserved heterogeneity. They also include year dummies, dummies that account for executives changing firm and position dummies. Standard errors are clustered at the 4 digit SIC level.

See Notes to Table 1 for a definition of all other variables and exact samples.

\begin{tabular}{|c|c|c|c|c|c|c|}
\hline & $\ln ($ Sal.+Bon. $)$ & $\ln$ (Total Comp.) & $\ln ($ Sal.+Bon. $)$ & $\ln ($ Total Comp.) & $\ln ($ Sal.+Bon. $)$ & $\ln ($ Total Comp.) \\
\hline & 1 & 2 & 3 & 4 & 5 & 6 \\
\hline \multirow[t]{2}{*}{ FIN94 } & -0.0382 & 0.0706 & & & & \\
\hline & {$[0.0354]$} & {$[0.0595]$} & & & & \\
\hline \multirow[t]{2}{*}{ FIN94b } & & & -0.0009 & 0.0578 & & \\
\hline & & & {$[0.0246]$} & {$[0.0402]$} & & \\
\hline \multirow[t]{2}{*}{ FIN99 } & & & & & 0.0013 & 0.0177 \\
\hline & & & & & [0.0433] & {$[0.0536]$} \\
\hline Year dummies & yes & yes & yes & yes & yes & yes \\
\hline Individual-firm specific FE & yes & yes & yes & yes & yes & yes \\
\hline Observations & 9916 & 8421 & 8826 & 7453 & 22736 & 19474 \\
\hline R-squared & 0.306 & 0.267 & 0.295 & 0.246 & 0.255 & 0.113 \\
\hline
\end{tabular}

* significant at $10 \% ; * *$ significant at $5 \% ; * * *$ significant at $1 \%$ 


\section{Table 4: Banking Sector Deregulation 1994: Effect on Performance-Pay Sensitivities}

In the 1994 specification, FIN94 takes value 1 if the individual is in the banking sector after 1994 , 0 otherwise. In the 1994b specification, FIN94 takes value 1 if the individual is in the banking sector after the Riegle-Neal bill is passed in the sate where the bank is incorporated and zero otherwise. The dummy variable Treated94 takes value 1 if the firm belongs to the banking sector. $\ln$ (Performance) is measured as the log of shareholder wealth. All regressions contain firm specific individual effects, therefore account for sector, firm and individual permanent unobserved heterogeneity (except col 4a and b that contain standard individual fixed effects, not firm-specific, and sector dummies) . They also include year dummies, dummies that account for executives changing firm and position dummies. Standard errors (in brackets) are clustered at the 4 digit SIC level.

See Notes to Table 1 for a definition of all other variables and exact samples.

\begin{tabular}{|c|c|c|c|c|c|c|c|c|}
\hline & \multicolumn{2}{|c|}{$\ln ($ Sal.+Bon. $)$} & \multicolumn{2}{|c|}{$\ln ($ Total Comp.) } & \multicolumn{2}{|c|}{$\ln$ (Total Comp.) } & \multicolumn{2}{|c|}{$\ln ($ Total Comp.) } \\
\hline & 1994 & $1994 b$ & 1994 & $1994 b$ & 1994 & $1994 b$ & 1994 & $1994 b$ \\
\hline & $1 \mathrm{a}$ & $1 b$ & $2 \mathrm{a}$ & $2 \mathrm{~b}$ & $3 \mathrm{a}$ & $3 \mathrm{~b}$ & $4 \mathrm{a}$ & $4 \mathrm{~b}$ \\
\hline \multirow[t]{2}{*}{$\ln$ (Performance) } & $0.0821^{* * *}$ & $0.0805^{* * *}$ & $0.1347^{* * *}$ & $0.1465^{* * *}$ & $0.1301^{* * *}$ & $0.1602^{* * *}$ & $0.1540^{* * *}$ & $0.1601^{* * *}$ \\
\hline & {$[0.0271]$} & {$[0.0264]$} & {$[0.0294]$} & {$[0.0291]$} & {$[0.0373]$} & {$[0.0321]$} & {$[0.0151]$} & {$[0.0153]$} \\
\hline \multirow[t]{2}{*}{ FIN94* $\ln$ (Performance) } & $0.0374^{* * *}$ & $0.0763^{* * *}$ & 0.0166 & $0.0478^{* *}$ & 0.0066 & $0.0620^{* * *}$ & $0.0298^{*}$ & $0.0651^{* * *}$ \\
\hline & {$[0.0101]$} & {$[0.0060]$} & {$[0.0176]$} & {$[0.0174]$} & {$[0.0287]$} & {$[0.0142]$} & {$[0.0157]$} & {$[0.0196]$} \\
\hline \multirow[t]{2}{*}{ FIN94 } & $-0.4070^{* * *}$ & $-0.6796^{* * *}$ & -0.1883 & $-0.4142^{* * *}$ & 2.4168 & $-0.4726^{* * *}$ & $-0.3061^{* *}$ & $-0.5622^{* * *}$ \\
\hline & {$[0.0707]$} & {$[0.0430]$} & {$[0.1371]$} & {$[0.1367]$} & [1.9899] & {$[0.1421]$} & {$[0.1265]$} & {$[0.1644]$} \\
\hline \multirow[t]{2}{*}{ Treated $94^{*} \ln ($ Performance $)$} & 0.0348 & 0.013 & $0.0648^{*}$ & 0.0397 & $0.0836^{*}$ & 0.0357 & $0.0817^{* * *}$ & $0.0549^{*}$ \\
\hline & {$[0.0395]$} & [0.0308] & {$[0.0346]$} & {$[0.0448]$} & [0.0459] & {$[0.0506]$} & {$[0.0275]$} & {$[0.0299]$} \\
\hline \multirow[t]{2}{*}{ Post94*ln(Performance) } & -0.0017 & 0.0008 & $0.0281^{*}$ & 0.0137 & 0.0489 & 0.0119 & $0.0297^{* * *}$ & $0.0156^{* *}$ \\
\hline & {$[0.0065]$} & {$[0.0047]$} & {$[0.0149]$} & {$[0.0175]$} & {$[0.0303]$} & {$[0.0171]$} & {$[0.0063]$} & {$[0.0065]$} \\
\hline \multirow[t]{2}{*}{$\ln$ (Sector Performance) } & & & & & -0.1336 & -0.1608 & & \\
\hline & & & & & {$[0.1023]$} & {$[0.0957]$} & & \\
\hline \multirow[t]{2}{*}{ FIN94* $\ln$ (Sector Perf.) } & & & & & -0.3174 & 0.0015 & & \\
\hline & & & & & {$[0.2573]$} & {$[0.0105]$} & & \\
\hline Year dummies & yes & yes & yes & yes & yes & yes & yes & yes \\
\hline Sector dummies & & & & & & & yes & yes \\
\hline Individual-firm specific FE & yes & yes & yes & yes & yes & yes & no & no \\
\hline Observations & 9437 & 8371 & 8072 & 7128 & 8072 & 7128 & 8072 & 7128 \\
\hline R-squared & 0.313 & 0.302 & 0.312 & 0.284 & 0.317 & 0.289 & 0.328 & 0.300 \\
\hline
\end{tabular}

* significant at $10 \% ; * *$ significant at $5 \% ; * * *$ significant at $1 \%$ 


\section{Table 5: Financial Services Deregulation 1999: Effect on Performance-Pay Sensitivities}

FIN99 takes value 1 if the individual is in the financial services sector after 1999, 0 otherwise. Treated99 takes value 1 for executives in the financial services sector, 0 otherwise. $\ln$ (Performance) is the log of shareholder wealth. All regressions contain firm specific individual effects, therefore account for sector, firm and individual permanent unobserved heterogeneity (except col 4 that contains standard individual fixed effects, not firm-specific and sector dummies). They also include year dummies, dummies that account for executives changing firm and position dummies. Standard errors (in brackets) are clustered at the 4 digit SIC level.

See Notes to Table 1 for a definition of all other variables and exact samples.

\begin{tabular}{|c|c|c|c|c|}
\hline & $\ln ($ Sal.+Bon.) & $\ln ($ Total Comp.) & $\ln ($ Total Comp.) & $\ln ($ Total Comp.) \\
\hline & 1 & 2 & 3 & 4 \\
\hline \multirow[t]{2}{*}{$\ln ($ Performance $)$} & $0.0745^{* * *}$ & $0.1147^{* * *}$ & $0.1187^{* * *}$ & $0.1203^{* * *}$ \\
\hline & {$[0.0097]$} & {$[0.0123]$} & {$[0.0146]$} & {$[0.0082]$} \\
\hline \multirow[t]{2}{*}{ FIN99*ln(Performance) } & -0.0048 & $0.0507^{* *}$ & 0.0427 & $0.0502^{* * *}$ \\
\hline & {$[0.0185]$} & {$[0.0202]$} & {$[0.0265]$} & {$[0.0140]$} \\
\hline \multirow[t]{2}{*}{ FIN99 } & 0.0342 & $-0.2986^{*}$ & $-1.6846^{* *}$ & $-0.3020 * * *$ \\
\hline & {$[0.1552]$} & {$[0.1624]$} & {$[0.7863]$} & {$[0.1052]$} \\
\hline \multirow[t]{2}{*}{ Treated $99^{*} \ln ($ Performance $)$} & $0.0330^{*}$ & 0.0228 & 0.0342 & 0.0254 \\
\hline & {$[0.0178]$} & {$[0.0258]$} & {$[0.0285]$} & {$[0.0159]$} \\
\hline \multirow[t]{2}{*}{ Post99* $\ln ($ Performance $)$} & -0.0051 & $-0.0249 * * *$ & -0.0278 & $-0.0243^{* * *}$ \\
\hline & {$[0.0061]$} & {$[0.0084]$} & {$[0.0170]$} & {$[0.0056]$} \\
\hline \multirow[t]{2}{*}{$\ln ($ Sector Performance $)$} & & & -0.0106 & \\
\hline & & & {$[0.0349]$} & \\
\hline \multirow[t]{2}{*}{ FIN99* $\ln ($ Sector Performance) } & & & $0.2057^{*}$ & \\
\hline & & & {$[0.1141]$} & \\
\hline Year dummies & yes & yes & yes & yes \\
\hline Individual-firm specific FE & yes & yes & yes & no \\
\hline Observations & 21304 & 18440 & 18440 & 18440 \\
\hline R-squared & 0.267 & 0.129 & 0.13 & 0.139 \\
\hline
\end{tabular}

* significant at $10 \% ; * *$ significant at $5 \% ; * * *$ significant at $1 \%$ 


\section{Table 6: Option grant sensitivities}

Columns 1 and 2 correspond to the 1994 experiment. Columns 3 and 4 to the $1994 \mathrm{~b}$ experiment and columns 5 and 6 to the 1999 experiment.

The dependent variable "Opt Grant" is the dollar sensitivity of the value of all the option grants received by the executive in a given year per $\$ 1000$ increase of shareholders' value.

FIN94, FIN94b and FIN99 captures the increase in the sensitivity of stock option grants following each experiment. FIN94 takes value 1 if the individual is in the Banking sector after 1994, 0 otherwise. FIN94b takes value 1 if the individual is in the banking sector after the Riegle-Neal bill is passed in the sate where the bank is incorporated and zero otherwise. FIN99 takes value 1 if the individual is in the financial services sector after 1999, 0 otherwise. Treated 99 takes value 1 for executives in the financial services sector, 0 otherwise. All regressions contain firm specific individual effects, therefore account for sector, firm and individual permanent unobserved heterogeneity. They also include year dummies, dummies that account for executives changing firm and position dummies. Standard errors are clustered at the 4 digit SIC level.

See Notes to Table 1 for a definition of all other variables and exact samples.

\begin{tabular}{|c|c|c|c|c|c|c|}
\hline & $\begin{array}{c}\text { Opt.grant. } \\
1\end{array}$ & $\begin{array}{c}\text { Opt.grant. } \\
2\end{array}$ & $\begin{array}{c}\text { Opt.grant. } \\
3\end{array}$ & $\begin{array}{c}\text { Opt.grant. } \\
4\end{array}$ & $\begin{array}{c}\text { Opt.grant. } \\
5\end{array}$ & $\begin{array}{c}\text { Opt.grant. } \\
6\end{array}$ \\
\hline \multirow[t]{2}{*}{ FIN94 } & 0.32 & $0.55^{*}$ & & & & \\
\hline & {$[0.19]$} & {$[0.30]$} & & & & \\
\hline \multirow[t]{2}{*}{ FIN94b } & & & 0.22 & $0.36^{* *}$ & & \\
\hline & & & {$[0.13]$} & {$[0.14]$} & & \\
\hline \multirow[t]{2}{*}{ FIN99 } & & & & & $0.37^{* *}$ & 0.26 \\
\hline & & & & & {$[0.18]$} & {$[0.20]$} \\
\hline Year dummies & yes & yes & yes & yes & yes & yes \\
\hline Individual $\mathrm{FE}$, firm specific? & yes & yes & yes & yes & yes & yes \\
\hline Sector trend & no & yes & no & yes & no & yes \\
\hline Observations & 8424 & 8424 & 7456 & 7456 & 19500 & 19500 \\
\hline R-squared & 0.0074 & 0.0078 & 0.00718 & 0.0073 & 0.0071 & 0.0071 \\
\hline
\end{tabular}

significant at $10 \% ; * *$ significant at $5 \% ; * * *$ significant at $1 \%$ 


\section{Appendix}

Expressions 3 and 4 capture the difference in differences effect of the deregulations on pay sensitivities. A test for the existence of differential preexisting trends between treated and non-treated industries consists in interacting directly the year dummies with the treatment variable, as well as with the product of treatment with performance. This allows for performing two additional checks. First, by checking the pattern of the coefficients before the deregulations take place we can check that there was not a clear differential trend between treated and non treated sectors. Second, we can perform a statistical test that compares the average of the performance-related coefficients prior to the deregulation to the sum of the coefficients after the deregulation. This test would be like a two stage version of the previous difference in differences approach in which all years have equal weights (i.e. as if we had a complete panel).

Table 7 performs the analysis for the 1994 experiment. Columns 1 and 2 perform the analysis using the log of salary and bonus and the log of total compensation as dependent variables. Each year dummy is interacted with the "Treated94" and the "Treated94*performance" variable to get estimates of the year-by-year differences between treated and non treated sectors on fixed and variable pay respectively. Year dummies, sector dummies and their interactions with performance are also included (coefficients not reported). Column 3 performs the same analysis but using option grant slopes, because the variable is in itself a slope the variables interacting with performance are not included in this specification. Standard errors are clustered at the 4 SIC digit level

While the presence of pre-existing trends in slope are hard to judge with only 2 observations, there does not seem to be a clear pattern across specifications (no trend for total compensation and for option grants and somewhat upward trend for salary and bonus). In terms of fixed pay, there is no pre-existing trend in total compensation but possibly a negative one in salary plus bonus.

At the bottom of the table we perform tests that show whether the average of the slopes after 1994 exceeds the average slope pre 1994. The results replicate the ones obtained in Section 4.3 and Section 4.4 with a clear substitution of fixed pay for variable pay in the salary and bonus specification, an increase in the slope of the options granted and inconclusive results with respect to the log of total pay.

Table 8 performs the analysis for the 1999 experiment. In this case it is easier to see that there are no clear pre-existing trends up to 1998 on any of the pay measures. With respect to comparing the average coefficients before and after, the results in this case are less clear, achieving statistically significant results only in the case of option grant slopes. There seems to be a clear spike in performance-related pay in 1999, but this fades away in subsequent years. The reason why the test of the average slopes might fail in this regression while it was quite significant in Section 4.3 has to do partly with a low precision when estimating individual year performance-related pay slopes as in this section we only use within sector year variation to estimate them and we implicitly discard valuable within firm variation of both pay and performance along different years. 
Table 7: Year by Year Slope Estimates 1994 Experiment

a) Treated94 is a dummy that takes value 1 for the banking sector; $\ln ($ Perf) is the logarithm of firm performance; year=1993 (=1994, etc.) is a dummy variable that equals 1 in 1993 (1994, etc.) . See Table 1 for exact definitions of all variables.

b) Standard errors clustered at the SIC4 digit level

\begin{tabular}{|c|c|c|c|}
\hline & $\begin{array}{c}\ln \text { (Sal.+Bon.) } \\
1\end{array}$ & $\begin{array}{c}\ln \text { (Total Comp.) } \\
2\end{array}$ & $\begin{array}{l}\text { Opt.grant.. } \\
3\end{array}$ \\
\hline \multirow[t]{2}{*}{ Treated94 X $\ln ($ Perf $)$ year $=1993$} & $0.070^{*}$ & 0.079 & \\
\hline & {$[0.041]$} & {$[0.051]$} & \\
\hline \multirow[t]{2}{*}{ Treated94 X $\ln ($ Perf $)$ year $=1994$} & 0.044 & $0.179^{* * *}$ & \\
\hline & {$[0.0386]$} & {$[0.03601]$} & \\
\hline \multirow[t]{2}{*}{ Treated $94 \mathrm{X} \ln ($ Perf $)$ year $=1995$} & 0.0482 & $0.08818^{* *}$ & \\
\hline & {$[0.0376]$} & {$[0.0393]$} & \\
\hline \multirow[t]{2}{*}{ Treated94 X $\ln ($ Perf $)$ year $=1996$} & $0.1041^{* *}$ & $0.1259^{* *}$ & \\
\hline & {$[0.0479]$} & {$[0.0468]$} & \\
\hline \multirow[t]{2}{*}{ Treated94 X $\ln ($ Perf $)$ year $=1997$} & $0.1545^{* * *}$ & $0.1845^{* * *}$ & \\
\hline & {$[0.044]$} & {$[0.0535]$} & \\
\hline \multirow{2}{*}{ Treated94 X $\ln ($ Perf $)$ year $=1998$} & $0.1154^{* * *}$ & $0.162^{* * *}$ & \\
\hline & {$[0.0356]$} & {$[0.053]$} & \\
\hline \multirow[t]{2}{*}{ Treated 94 year $=1993$} & $-0.325^{* *}$ & 0.091 & -0.00008 \\
\hline & {$[0.136]$} & {$[0.391]$} & {$[0.00015]$} \\
\hline \multirow{2}{*}{ Treated94 year $=1994$} & -0.116 & $-0.644^{* * *}$ & $-0.00061^{* *}$ \\
\hline & {$[0.155]$} & {$[0.173]$} & {$[0.00027]$} \\
\hline \multirow[t]{2}{*}{ Treated 94 year $=1995$} & -0.224 & 0.0021 & -0.00008 \\
\hline & {$[0.144]$} & {$[0.273]$} & {$[0.00015]$} \\
\hline \multirow[t]{2}{*}{ Treated 94 year $=1996$} & $-0.740 * *$ & -0.280 & 0.00005 \\
\hline & {$[0.262]$} & {$[0.288]$} & {$[0.00020]$} \\
\hline \multirow[t]{2}{*}{ Treated 94 year $=1997$} & $-1.214^{* * *}$ & $-0.949^{* *}$ & $-0.00028^{*}$ \\
\hline & {$[0.240]$} & {$[0.411]$} & {$[0.00016]$} \\
\hline \multirow[t]{2}{*}{ Treated 94 year $=1998$} & $-0.868^{* * *}$ & $-0.606^{*}$ & 0.00003 \\
\hline & {$[0.156]$} & {$[0.348]$} & {$[0.00023]$} \\
\hline Year dummies & yes & yes & yes \\
\hline Year dummies $\mathrm{X} \ln ($ Perf $)$ & yes & yes & no \\
\hline Sector dummies $\mathrm{X} \ln ($ Perf $)$ & yes & yes & no \\
\hline Individual FE, firm specific? & yes & yes & yes \\
\hline Observations & 9437 & 8072 & 9938 \\
\hline R-squared & 0.189 & 0.401 & 0.0086 \\
\hline Slope Up to $94<$ Slope Post94 (P value) & 0.003 & 0.693 & 0.101 \\
\hline Fixed Up to $94>$ Fixed Post94 (P value) & 0.000 & 0.009 & \\
\hline
\end{tabular}


Table 8: Year by Year Estimates 1999 Experiment

a) Treated99 is a dummy that takes value 1 for the banking sector; $\ln$ (Perf) is the logarithm of firm performance; year=1995 (=1996, etc.) is a dummy variable that equals 1 in 1995 (1996, etc.) . See Table 1 for exact definitions of all variables.

b) Standard errors clustered at a SIC4 digit level

\begin{tabular}{|c|c|c|c|}
\hline & $\begin{array}{c}\ln (\text { Sal.+Bon. }) \\
1\end{array}$ & $\begin{array}{c}\ln \text { (Total Comp.) } \\
2 \\
\end{array}$ & $\begin{array}{l}\text { Opt.grant. } \\
3\end{array}$ \\
\hline \multirow[t]{2}{*}{ Treated $99 \times \ln ($ Perf $)$ year $=1995$} & -0.0676 & 0.00149 & \\
\hline & {$[0.050]$} & {$[0.043]$} & \\
\hline \multirow[t]{2}{*}{ Treated99 X $\ln ($ Perf $)$ year $=1996$} & -0.0209 & -0.0201 & \\
\hline & {$[0.0429]$} & {$[0.030]$} & \\
\hline \multirow[t]{2}{*}{ Treated $99 \times \ln ($ Perf $)$ year $=1997$} & 0.0139 & 0.0310 & \\
\hline & {$[0.032]$} & {$[0.030]$} & \\
\hline \multirow[t]{2}{*}{ Treated99 X $\ln ($ Perf $)$ year $=1998$} & 0.0134 & 0.0417 & \\
\hline & {$[0.038]$} & {$[0.025]$} & \\
\hline \multirow[t]{2}{*}{ Treated $99 \times \ln ($ Perf $)$ year $=1999$} & $0.0622^{* *}$ & $0.0526^{* * *}$ & \\
\hline & {$[0.024]$} & {$[0.0184]$} & \\
\hline \multirow{2}{*}{ Treated99 X $\ln ($ Perf $)$ year $=2000$} & $0.0903^{* * *}$ & 0.0407 & \\
\hline & {$[0.0339]$} & {$[0.0309]$} & \\
\hline \multirow[t]{2}{*}{ Treated99 X $\ln ($ Perf $)$ year $=2001$} & 0.0239 & 0.0271 & \\
\hline & {$[0.0347]$} & {$[0.0250]$} & \\
\hline \multirow[t]{2}{*}{ Treated99 X $\ln ($ Perf $)$ year $=2002$} & 0.0238 & -0.0157 & \\
\hline & {$[0.0999]$} & {$[0.0507]$} & \\
\hline \multirow[t]{2}{*}{ Treated99 year $=1996$} & -0.2361 & 0.2678 & -0.00023 \\
\hline & {$[0.304]$} & {$[0.3080]$} & {$[0.00024]$} \\
\hline \multirow[t]{2}{*}{ Treated99 year $=1997$} & -0.4891 & -0.1348 & -0.00031 \\
\hline & {$[0.320]$} & {$[0.289]$} & {$[0.00022]$} \\
\hline \multirow[t]{2}{*}{ Treated99 year $=1998$} & -0.3860 & -0.2458 & -0.00023 \\
\hline & {$[0.3179]$} & {$[0.2384]$} & {$[0.00022]$} \\
\hline \multirow[t]{2}{*}{ Treated99 year $=1999$} & $-0.7698^{* *}$ & -0.2092 & $-0.00044^{* *}$ \\
\hline & {$[0.3639]$} & {$[0.4005]$} & {$[0.00019]$} \\
\hline \multirow[t]{2}{*}{ Treated99 year $=2000$} & $-1.0132 * * *$ & -0.2336 & -0.00012 \\
\hline & {$[0.3651]$} & {$[0.4423]$} & {$[0.00028]$} \\
\hline \multirow[t]{2}{*}{ Treated 99 year $=2001$} & -0.4800 & -0.1139 & -0.00024 \\
\hline & {$[0.3960]$} & {$[0.4663]$} & {$[0.00024]$} \\
\hline \multirow[t]{2}{*}{ Treated 99 year $=2002$} & -0.3195 & 0.2671 & 0.00007 \\
\hline & {$[0.8687]$} & {$[0.5754]$} & {$[0.00020]$} \\
\hline Year dummies & yes & yes & yes \\
\hline Year dummies $\mathrm{X} \ln ($ Perf $)$ & yes & yes & no \\
\hline Sector dummies $\mathrm{X} \ln$ (Perf) & yes & yes & no \\
\hline Individual FE, firm specific? & yes & yes & yes \\
\hline Observations & 9437 & 8072 & 9938 \\
\hline R-squared & 0.189 & 0.282 & 0.0086 \\
\hline Slope Up to $99<$ Slope Post99 (P value) & 0.809 & 0.645 & 0.132 \\
\hline Fixed Up to $99>$ Fixed Post99 (P value) & 0.746 & 0.439 & \\
\hline
\end{tabular}

